\title{
Familial empirical risks for inflammatory bowel disease: differences between Jews and non-Jews
}

\author{
H Yang, C McElree, M-P Roth, F Shanahan, S R Targan, J I Rotter
}

\begin{abstract}
The Jewish population has an increased frequency of inflammatory bowel disease compared with their non-Jewish neighbours. Genetic factors have been implicated in the aetiology of this disorder and may contribute to ethnic differences. This study determined the familial empirical risks for inflammatory bowel disease in the first degree relatives of inflammatory bowel disease probands (for both Jews and non-Jews) for the purpose of accurate genetic counselling and genetic analysis. A total of 527 inflammatory bowel disease patients from Southern California (291 Jews and 236 non-Jews) were questioned about inflammatory bowel disease in their first degree relatives (a total of 2493 individuals). Since inflammatory bowel disease has a variable and late age of onset, age specific incidence data were used to estimate the life time risks and to make valid comparisons between the different groups. In the first degree relatives of non-Jewish probands, the life time risks for inflammatory bowel disease were $5.2 \%$ and $1.6 \%$ when probands had Crohn's disease and ulcerative colitis respectively. These values were consistently lower than the corresponding risks for relatives of Jewish patients $\mathbf{- 7 . 8 \%}$ and $\mathbf{4 . 5 \%}$ for Crohn's disease and ulcerative colitis probands respectively ( $p$ value for comparison between Jews and non-Jews: 0.028; between ulcerative colitis and Crohn's disease: 0.005). These data provide the requisite basis for genetic counselling for these disorders in the white American population. In addition, these different empirical risks for relatives of Jewish and non-Jewish probands allow rejection of single Mendelian gene models for inflammatory bowel disease, but are consistent with several alternative genetic models.

(Gut 1993; 34: 517-524)
\end{abstract}

The aetiology and pathogenesis of the inflammatory bowel diseases remain unknown. Available epidemiological data show that the Jewish population has a higher risk of developing inflammatory bowel disease than other ethnic groups, three to four times higher than their nonJewish neighbours. ${ }^{1-3} W$ ithin the Jewish population, heterogeneity was found among the different historical ethnic subgroups, ${ }^{1+10}$ that is American or European Ashkenazi Jews seem to have an increased risk compared with Sephardic or Oriental Jews, ${ }^{148}$ and Ashkenazi Jews of middle European origin have an excess risk relative to those of Polish/Russian origin. ${ }^{910}$ Although the different incidence/prevalence among the different Jewish subgroups may suggest environmental aetiological agents, "the repeated observations that the Jewish population has a consistently increased incidence/prevalence compared with other ethnic groups in the same location, and that this occurs across different time periods as well as different geographical areas, ${ }^{312}$ indicates a genetic predisposition to develop this disease.

Both an increased frequency of a positive family history of inflammatory bowel disease among inflammatory bowel disease patients and an increased risk of inflammatory bowel disease in their relatives are the evidence for familial aggregation of the disease..$^{31-15}$ This familial aggregation of inflammatory bowel disease has been shown in both Jewish and non-Jewish families. The ethnic differences reviewed above and the familial aggregation might be the result of either genetic or environmental factors acting alone, or together. The increased monozygotic twin concordance rates, ${ }^{16}$ the rarity of inflammatory bowel disease concordance in spouses, ${ }^{14}$ 15 and the numerous instances of affected relatives whose disease onset is completely separated geographically and temporally from other affected family members, ${ }^{17}$ argues, however, for a major genetic component to disease susceptibility. In addition, the co-occurrence of ulcerative colitis and Crohn's disease in the same families suggests that these two disorders (or a subset of these disorders) share a common genetic background. ${ }^{315}$

We have previously reported familial empirical risk estimates of inflammatory bowel disease, as well as the more appropriate age adjusted risks for genetic counselling and modelling in Ashkenazi Jews in the United States. ${ }^{18}$ As there is a different population frequency of inflammatory bowel disease in Jews and non-Jews, these empirical risk data are needed for each group to provide more specific risk estimates for genetic counselling. In addition, the comparison of familial aggrega-

TABLE I Strömgren's method for calculation of age corrected risk estimates for inflammatory bowel disease

\begin{tabular}{|c|c|c|c|c|c|}
\hline $\begin{array}{l}\text { Age } \\
(y)\end{array}$ & $i$ & $a_{i}$ & $\begin{array}{l}b_{i} \\
(\%)\end{array}$ & $\begin{array}{l}c_{i} \\
(\%)\end{array}$ & $d_{i}$ \\
\hline $\begin{array}{l}<10 \\
10-19 \\
20-29 \\
30-39 \\
40-49 \\
50-59 \\
60-69 \\
70+ \\
\text { Total }\end{array}$ & $\begin{array}{l}1 \\
2 \\
3 \\
4 \\
5 \\
6 \\
7 \\
8\end{array}$ & $\begin{array}{r}0.70 \\
5 \cdot 26 \\
7.53 \\
5 \cdot 33 \\
5.90 \\
5 \cdot 34 \\
5 \cdot 20 \\
3.76 \\
39 \cdot 02\end{array}$ & $\begin{array}{r}1.79 \\
13.48 \\
19.30 \\
13.66 \\
15.12 \\
13.68 \\
13.33 \\
9.64 \\
100.00\end{array}$ & $\begin{array}{r}1 \cdot 79 \\
15 \cdot 27 \\
34.57 \\
48 \cdot 23 \\
63 \cdot 35 \\
77 \cdot 03 \\
90 \cdot 36 \\
100 \cdot 00\end{array}$ & $\begin{array}{l}0.0089 \\
0.0853 \\
0.2492 \\
0.4140 \\
0.5579 \\
0.7019 \\
0.8369 \\
0.9518\end{array}$ \\
\hline
\end{tabular}

$a_{i}=$ age specific incidence rates (per 100000 ) of ulcerative colitis and Crohn's disease for whites, Baltimore, 1977-1979. $b_{i}=$ proportion of total risk by age group, $b_{i}(\%)=a_{i} \times 100 \% / \Sigma a_{i}$. $c_{i}=$ cumulative proportional risk, $c_{i}(\%)=\Sigma b_{i}(\%)$.

$d_{i}=$ correction factor for ith age group, $d_{i}=\left(b_{i} / 2+c_{i}, 1\right) / 100$ 
tion of inflammatory bowel disease in these two ethnic groups may contribute to understanding of the aetiologies of the disorder.

In this study, we ascertained both Jewish and non-Jewish patients with inflammatory bowel disease from the same geographical area and determined the prevalence of inflammatory bowel disease in their first degree relatives. A comparison of the familial aggregation between these two groups was then made, taking into account the age distribution in relatives. The results indicate distinct empirical risks for each ethnic group.

\section{Methods}

\section{DATA COLLECTION}

We ascertained 759 patients with inflammatory bowel disease from two large west Los Angeles gastroenterology practices and from the UCLA inflammatory bowel disease clinical programme during the period from 1986 to 1991 . The patient composition of these practices is mostly, but not exclusively, white and of middle and upper socioeconomic status. A letter explaining the study was mailed to all patients. Of 759 initial letters sent out, 174 potential subjects were eliminated because they had died, moved house, or further information indicated that a diagnosis of inflammatory bowel disease was incorrect. Among the remaining 585 eligible patients, 567 were interviewed via telephone or at a clinical visit, and completed the requisite pedigree information $(96 \cdot 9 \%)$. Only $18(3 \cdot 1 \%)$ refused to participate in this study. Of 567 completed interviews, 28 were non-white subjects and these were omitted from the analyses conducted here. To reduce the heterogeneity in the patient population, the 12 cases whose diagnosis was indeterminate colitis were also excluded from the current report. This resulted in 527 probands, through whom we collected information regarding inflammatory bowel disease in their 2493 first degree relatives.

The diagnosis of ulcerative colitis or Crohn's disease had been made by the referring gastroenterologists and documented by endoscopic, radiological, surgical, and pathological reports. Data collected included diagnosis, age, sex, age at onset of disease, age at diagnosis, pedigree, and ethnicity. As this is an amnestic study, we evaluated the diagnosis of inflammatory bowel disease in relatives by asking the index cases detailed information regarding the symptoms, treatment, and the course of the disease in their relatives. We have also contacted more than $70 \%$ of the affected relatives themselves to verify the diagnosis of ulcerative colitis or Crohn's disease. In many cases $(43 \%)$, medical records were obtained for further confirmation. Thus, describing the relative as having 'colitis' or 'bowel problems' was not considered sufficient to classify him or her as affected. A positive family history was defined as the existence of at least one other blood relative, who could be as distant as third degree (for example cousin, grandparent, etc), who had either ulcerative colitis or Crohn's disease. In addition, all index cases were unrelated to each other. In this study, we defined as a Jewish proband those individuals with at least one out of four grandparents of Jewish origin. In addition, Jewish as specified here refers to Ashkenazi Jewish.

\section{STATISTICAL ANALYSIS}

The crude prevalence of ulcerative colitis or Crohn's disease in the relatives at the time of the study was calculated by dividing the number of affected relatives by the total number of relatives of the same category. The analyses were performed for each category of the probands' first degree relatives (siblings, parents, children).

Age adjusted empirical risk estimates for siblings, parents, and children were then calculated using Strömgren's method of age correction..$^{1920}$ The importance of performing these calculations is that inflammatory bowel disease is not present at birth, so a true estimate of the risk is obtained only when one takes into account the period of life that an individual has lived through. The cumulative proportional risk of developing inflammatory bowel disease up to an age of 70 years was calculated from the age specific incidence data per decade in Baltimore published by Calkins $e t a l^{21}$ for both ulcerative colitis and Crohn's disease (see Table I), as there is no available population incidence data specifically from Los Angeles.

The age specific incidence rates of inflammatory bowel disease $\left(a_{i}\right)$ provided the basis for calculating the correction factor for the age adjustment by Strömgren's method (Table I). The proportion of risk by age group $\left(b_{i}\right)$ was calculated by dividing the incidence rate in an age group over the total risk, which is the sum of all age specific incidence rates; specifically, $b_{i}(\%)=a_{i} \times 100 \% / \Sigma a_{i}$, (for example for the 2 nd age group (age 10-19 years), $b_{2}=a_{2} \times 100 \% / a_{1}+$ $\left.\left.a_{2}+\ldots+a_{8}\right)=5 \cdot 26 \times 100 \% / 39 \cdot 02=13 \cdot 48 \%\right)$. The cumulative proportional risk was defined as the sum of the risks up to a certain age - that is, $c_{i}(\%)=\Sigma b_{j}(\%)$ (for example for the 3rd age group, $\quad c_{3}=b_{1}+b_{2}+b_{3}=1 \cdot 79+13 \cdot 48+19 \cdot 30=$ $34 \cdot 57 \%)$. The correction factor was calculated from the cumulative proportional risk by assuming an evenly distributed risk in each age interval, $\mathrm{d}_{\mathrm{i}}=\left(\mathrm{b}_{\mathrm{i}} / 2+\mathrm{c}_{\mathrm{i}-1}\right) / 100$ (for example for the 4th age group, $d_{4}=b_{4} / 2+c_{3}=13 \cdot 66 \% / 2+34 \cdot 57 \%=$ $41 \cdot 4 \%$, that is, $0 \cdot 414)$. The number of first degree relatives in each age group was multiplied by the specific correction factor to give an age adjusted number of relatives at risk. The number of relatives with inflammatory bowel disease divided by the age adjusted total number of relatives at risk yields the theoretical risk of developing inflammatory bowel disease to 70 years of age, that is, the prevalence of inflammatory bowel disease assuming that all relatives will reach the age of 70 years and that these relatives have a similar distribution of proportional risk as that reported by Calkins et al. ${ }^{21}$ The result is thereby independent of the actual age distribution. It is, therefore, optimal to use these age adjusted empirical risk estimates to compare familial aggregation between Jews and non-Jews or between other populations.

Statistical analyses included Student's $t$ tests for quantitative traits, for example, age at onset, 
and $\chi^{2}$ tests for qualitative variables. The $95 \%$ confidence intervals of the prevalence estimates were estimated according to the assumption that the number of cases followed a Poisson distribution when the affected frequency was less than 15. ${ }^{22}$ The adjusted empirical risk of inflammatory bowel disease (ulcerative colitis or Crohn's) was estimated separately for relatives of probands with ulcerative colitis and those of probands with Crohn's disease. Because of the number of affected relatives, we did not attempt to calculate separate age adjusted empirical risk estimates for ulcerative colitis and Crohn's disease individually in relatives. The comparisons of crude or adjusted empirical risks between groups, for example Jewish $v$ nonJewish probands and ulcerative colitis $v$ Crohn's disease probands, were tested by MantelHaenszel statistics. ${ }^{23}$

\section{Results}

PROBAND AND FAMILY PATTERNS

Table II shows the distribution of probands by ethnicity, type of inflammatory bowel disease, and the (male/female) sex ratio.

Family size (number of first degree relatives) ranged from 2 to 19 with a median of 4 for both Jews and non-Jews, and a mean of 4.5 for Jews and $5 \cdot 1$ for non-Jews. There were 39 Jewish families and 15 non-Jewish families with at least one additional relative affected with inflammatory bowel disease among the first degree relatives of the inflammatory bowel disease probands (see Table III). Among these multiply affected families, $10(26 \%)$ of the Jewish families and 8 $(53 \%)$ of the non-Jewish families include both ulcerative colitis and Crohn's disease affected individuals in the same family $(p=0.053)$.

AGE AT ONSET OF INFLAMMATORY BOWEL DISEASE IN PROBANDS

The probands with Crohn's disease had a younger age of onset $(23 \cdot 1(14 \cdot 0), \mathrm{n}=257)$ than those with ulcerative colitis $(27 \cdot 7(16 \cdot 6), n=267)$. The difference was highly significant $(p<0 \cdot 001)$. The age at diagnosis was on the average 4 years later than the age at onset. The analysis of age at diagnosis of disease showed the same difference between ulcerative colitis and Crohn's disease probands as that indicated in the analysis of age at onset. This was true for all additional analyses.

When the comparisons of age at onset between ulcerative colitis and Crohn's disease were stratified by the presence or absence of a family history of inflammatory bowel disease, the difference between ulcerative colitis and Crohn's disease disappeared for those individuals with a positive

TABLE II Proband distribution by ethnicity, inflammatory bowel disease, and sex ratio (male/female)

\begin{tabular}{|c|c|c|c|c|c|c|}
\hline & \multicolumn{2}{|l|}{ fews } & \multicolumn{2}{|c|}{ Non-fews } & \multicolumn{2}{|c|}{ Total } \\
\hline & No & Sex ratio & No & Sex ratio & No & Sex ratio \\
\hline $\begin{array}{l}\text { Ulcerative colitis } \\
\text { Crohn's disease } \\
\text { Total }\end{array}$ & $\begin{array}{l}157 \\
134 \\
291\end{array}$ & $\begin{array}{l}1 \cdot 3 \\
0.9 \\
1 \cdot 1\end{array}$ & $\begin{array}{l}112 \\
124 \\
236\end{array}$ & $\begin{array}{l}1 \cdot 2 \\
0 \cdot 8 \\
1 \cdot 0\end{array}$ & $\begin{array}{l}269 \\
258 \\
527\end{array}$ & $\begin{array}{l}1 \cdot 2 \\
0 \cdot 8 \\
1 \cdot 0\end{array}$ \\
\hline
\end{tabular}

TABLE III Distribution of affected individuals in Fewish and non-fewish families

\begin{tabular}{lrrrrr}
\hline & \multicolumn{6}{c}{ No of families with n affected individuals } \\
\cline { 2 - 6 } Type of family & $n=1$ & $n=2$ & $n=3$ & $n=4$ & Total \\
\hline Jews: & 139 & 17 & 0 & 0 & 156 \\
$\quad$ Ulcerative colitis only & 113 & 10 & 1 & 1 & 125 \\
$\quad$ Crohn's disease only & 0 & 7 & 3 & 0 & 10 \\
$\quad$ Mixed & 252 & 34 & 4 & 1 & 291 \\
Total & & & & & \\
Non-Jews: & 108 & 1 & 1 & 0 & 110 \\
$\quad$ Ulcerative colitis only & 113 & 3 & 1 & 1 & 118 \\
$\quad$ rrohn's disease only & 0 & 5 & 3 & 0 & 8 \\
$\quad$ Mixed & 221 & 9 & 5 & 1 & 236 \\
\hline Total & &
\end{tabular}

^Mixed: families with both ulcerative colitis and Crohn's disease patients.

TABLE IV Comparison of age at onset of ulcerative colitis and Crohn's disease probands

\begin{tabular}{|c|c|c|c|}
\hline & $\begin{array}{l}\text { Ulcerative colitis } \\
(\text { mean }(S D)(\text { no }))^{\star}\end{array}$ & $\begin{array}{l}\text { Crohn's disease } \\
(\text { mean }(S D)(\text { no }))^{\star}\end{array}$ & pvalue \\
\hline Overall total & $27 \cdot 7(16 \cdot 6)(267)$ & $23 \cdot 1(14 \cdot 0)(257)$ & 0.0006 \\
\hline $\begin{array}{l}\text { Positive } \\
\text { family history }\end{array}$ & $23 \cdot 3(15 \cdot 0)(47)$ & $23 \cdot 3(15 \cdot 1)(59)$ & 0.981 \\
\hline $\begin{array}{l}\text { Negative } \\
\text { family history }\end{array}$ & $28 \cdot 6(16 \cdot 8)(220)$ & $23 \cdot 0(13 \cdot 7)(198)$ & 0.0003 \\
\hline $\begin{array}{l}\text { Jews, total } \\
\text { Positive } \\
\text { family history }\end{array}$ & $\begin{array}{l}28 \cdot 7(16 \cdot 8)(156) \\
24 \cdot 8(14 \cdot 6)(35)\end{array}$ & $\begin{array}{l}24 \cdot 1(14 \cdot 8)(133) \\
24 \cdot 0(17 \cdot 6)(36)\end{array}$ & $\begin{array}{l}0.014 \\
0.836\end{array}$ \\
\hline $\begin{array}{l}\text { Negative } \\
\text { family history }\end{array}$ & $29 \cdot 8(17 \cdot 3)(121)$ & $24 \cdot 1(13 \cdot 7)(97)$ & 0.008 \\
\hline Non-Jews, total & $26 \cdot 3(16 \cdot 3)(111)$ & $22 \cdot 0(13 \cdot 2)(124)$ & 0.026 \\
\hline $\begin{array}{l}\text { Positive } \\
\text { family history }\end{array}$ & $19 \cdot 0(16 \cdot 0)(12)$ & $22 \cdot 1(10 \cdot 3)(23)$ & 0.493 \\
\hline $\begin{array}{l}\text { Negative } \\
\text { family history }\end{array}$ & $27 \cdot 2(16 \cdot 2)(99)$ & $22 \cdot 0(13 \cdot 8)(101)$ & 0.015 \\
\hline
\end{tabular}

${ }^{\star}$ Mean (SD) (number of probands whose age at onset was recorded, three with missing data).

family history (Table IV). Among ulcerative colitis patients, the age at onset of disease was lower in those with a positive family history than in those with a negative family history - ages $23 \cdot 3$ and 28.6 years, respectively $(\mathrm{p}<0.05)$. In contrast, there was no significant difference of age at onset among Crohn's disease patients between those with or without a positive family history. The same relationships between age at onset and family history were observed in both Jewish and non-Jewish patients (the lower portions of the Table IV).

Although non-Jewish patients had a younger age of onset than Jewish patients $(24 \cdot 1)(14 \cdot 9) v$ $26 \cdot 6(16 \cdot 1)$, the difference was not of sufficient magnitude to attain statistical significance $(\mathrm{p}=0 \cdot 07)$.

\section{POSITIVE FAMILY HISTORY OF INFLAMMATORY} BOWEL DISEASE

Of the 258 patients with Crohn's disease, there were $60(23.3 \%)$ with a positive family history, while among patients with ulcerative colitis, 47 out of $269(17 \cdot 5 \%)$ had a positive family history. Table $\mathrm{V}$ shows the distribution of affected relatives by the clinical type of disease. The data show: (1) that the greatest risk to relatives is for the same disease occurring as in the index cases; (2) that affected relatives may develop either form of inflammatory bowel disease; and (3) that Crohn's disease probands tend to have a much higher frequency of relatives affected with ulcer- 
ative colitis than ulcerative colitis probands have relatives affected with Crohn's disease $(10.9 \% v$ $3.7 \%, \mathrm{p}<0.002)$. This is true even when first degree relatives only were considered in the analysis $(6.6 \% v 1.5 \%, \mathrm{p}=0.021)$. This pattern held for both Jewish and non-Jewish families.

Jewish probands had an increased positive family history compared with non-Jewish probands, $24 \cdot 3 \%$ and $14.6 \%$, respectively ( $<<0.01$ ). This is true for ulcerative colitis and Crohn's disease probands analysed separately $(22.3 \% v$ $10.7 \%$ for ulcerative colitis, $\mathrm{p}=0.014$; and $26.6 \%$ $v 18 \cdot 1 \%$ for Crohn's disease, $\mathrm{p}=0.097$ ).

EMPIRICAL RISKS IN THE FIRST DEGREE RELATIVES The crude, uncorrected empirical risks in the first degree relatives of Jewish and non-Jewish probands are summarised in Table VI (A), separately by both type of relationship (siblings, parents, offspring, and all first degree relatives) and by type of proband - that is those with Crohn's disease or ulcerative colitis. Table VI (B)

TABLE V Positive family history of inflammatory bowel disease in uclerative colitis (UC) and Crohn's disease $(C D)$ probands *

\begin{tabular}{|c|c|c|c|c|c|c|}
\hline \multirow[b]{2}{*}{ Disease in proband } & \multirow{2}{*}{$\begin{array}{l}\text { No of } \\
\text { probands }\end{array}$} & \multicolumn{4}{|c|}{ Disease in relatives } & \multirow{2}{*}{$\begin{array}{l}\text { pvalues } \\
\text { UV vCD } \\
\text { relatives }\end{array}$} \\
\hline & & $U C(\%)$ & $C D(\%)$ & Mixed (\%)† & Total $(\%)$ & \\
\hline $\begin{array}{l}\mathrm{UC} \\
\mathrm{CD} \\
\text { p value (UC } v \mathrm{CD} \text { probands) } \\
\text { Total }\end{array}$ & $\begin{array}{l}269 \\
258 \\
527\end{array}$ & $\begin{array}{l}37(13 \cdot 8) \\
19(7 \cdot 4) \\
0 \cdot 017 \\
56(10 \cdot 6)\end{array}$ & $\begin{array}{c}6(2 \cdot 2) \\
32(12 \cdot 4) \\
0 \cdot 000 \\
38(7 \cdot 2)\end{array}$ & $\begin{array}{c}4(1 \cdot 5) \\
9(3 \cdot 5) \\
0 \cdot 139 \\
13(2 \cdot 5)\end{array}$ & $\begin{array}{c}47(17 \cdot 5) \\
60(23 \cdot 3) \\
0 \cdot 099 \\
107(20 \cdot 3)\end{array}$ & $\begin{array}{l}<0.001 \\
0.1>p>0.05\end{array}$ \\
\hline $\begin{array}{l}\text { First degree relatives only: } \\
\text { UC } \\
\text { CD } \\
\text { p value (UC } v \text { CD probands) } \\
\text { Total }\end{array}$ & $\begin{array}{l}269 \\
258 \\
527\end{array}$ & $\begin{array}{c}19(7 \cdot 1) \\
13(5 \cdot 0) \\
0 \cdot 331 \\
32(6 \cdot 1)\end{array}$ & $\begin{array}{c}4(1 \cdot 5) \\
19(7 \cdot 4) \\
0 \cdot 001 \\
23(4 \cdot 4)\end{array}$ & $\begin{array}{l}0 \\
4(1 \cdot 6) \\
0 \cdot 040 \\
4(0 \cdot 8)\end{array}$ & $\begin{array}{l}23(8 \cdot 6) \\
36(14 \cdot 0) \\
0 \cdot 049 \\
59(11 \cdot 2)\end{array}$ & $\begin{array}{l}<0.005 \\
>0.25\end{array}$ \\
\hline
\end{tabular}

^Both Jews and non-Jews have the same trend.

tWith several affected relatives, some affected with ulcerative colitis and some with Crohn's disease. $\neq \mathrm{p}$ values from the $\chi^{2}$ test of goodness of fit with the null hypothesis that the frequency of a positive history of ulcerative colitis is equal to the frequency of a positive history of Crohn's disease in either ulcerative colitis or Crohn's disease probands.

TABLE VI $(A)$ Prevalence of inflammatory bowel disease in first degree relatives of patients with inflammatory bowel disease (\%)

\begin{tabular}{|c|c|c|c|c|}
\hline & Siblings $\%$ (no) & Parents \% (no) & Offspring \% (no) & $\begin{array}{l}\text { All first degree } \\
\%(\text { no })\end{array}$ \\
\hline $\begin{array}{l}\text { Jews: } \\
\text { CD patients } \\
\text { UC patients }\end{array}$ & $\begin{array}{l}8 \cdot 0(199) \\
2 \cdot 4(252)\end{array}$ & $\begin{array}{l}3 \cdot 0(265) \\
3 \cdot 2(313)\end{array}$ & $\begin{array}{l}1.8(111) \\
1.9(157)\end{array}$ & $\begin{array}{l}4 \cdot 5(575) \\
2 \cdot 6(722)\end{array}$ \\
\hline $\begin{array}{l}\text { Non-Jews: } \\
\text { CD patients } \\
\text { UC patients }\end{array}$ & $\begin{array}{l}3 \cdot 0(268) \\
0 \cdot 4(258)\end{array}$ & $\begin{array}{l}3 \cdot 7(246) \\
0.9(220)\end{array}$ & $\begin{array}{l}0(117) \\
2 \cdot 3(87)\end{array}$ & $\begin{array}{l}2 \cdot 7(631) \\
0 \cdot 9(565)\end{array}$ \\
\hline \multicolumn{3}{|c|}{ 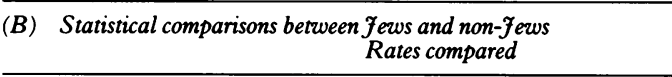 } & $\chi_{M H^{2}}$ & pvalue \\
\hline $\begin{array}{l}\text { All first degree relatives: } \\
\text { CD probands } \\
\text { UC probands } \\
\text { All probands }\end{array}$ & $\begin{array}{l}(8 \cdot 0,3 \\
(2 \cdot 4,3 \\
(4 \cdot 5,2\end{array}$ & $\begin{array}{l}1 \cdot 8) v(3 \cdot 0,3 \cdot 7,0) \\
1 \cdot 9) v(0 \cdot 4,0 \cdot 9,2 \cdot 3) \\
v(2 \cdot 7,0 \cdot 9)\end{array}$ & $\begin{array}{l}2 \cdot 95 \\
4 \cdot 01 \\
6 \cdot 87\end{array}$ & $\begin{array}{l}0.086 \\
0.045 \\
0.009\end{array}$ \\
\hline $\begin{array}{l}\text { Siblings only: } \\
\text { CD probands } \\
\text { UC probands } \\
\text { All probands }\end{array}$ & $\begin{array}{l}(8 \cdot 0) v \\
(2 \cdot 4) v \\
(8 \cdot 0,2\end{array}$ & $\begin{array}{l}\cdot 0) \\
\cdot 4) \\
v(3 \cdot 0,0 \cdot 4)\end{array}$ & $\begin{array}{l}5.99 \\
3 \cdot 76 \\
8 \cdot 35\end{array}$ & $\begin{array}{l}0.014 \\
0.052 \\
0.004\end{array}$ \\
\hline (C) Statistical comparison & $\begin{array}{r}\text { is between } C D \text { and } \\
\text { Rates } c\end{array}$ & $\begin{array}{l}\text { JC } \\
\text { epared }\end{array}$ & $\chi_{M H^{2}}$ & pvalue \\
\hline $\begin{array}{l}\text { All first degree relatives: } \\
\text { Jewish probands } \\
\text { Non-Jewish probands } \\
\text { All probands }\end{array}$ & $\begin{array}{l}(8 \cdot 0,3 . \\
(3 \cdot 0,3 . \\
(4 \cdot 5,2 .\end{array}$ & $\begin{array}{l}1 \cdot 8) v(2 \cdot 4,3 \cdot 2,1 \cdot 9) \\
0) v(0 \cdot 4,0 \cdot 9,2 \cdot 3) \\
v(2 \cdot 6,0 \cdot 9)\end{array}$ & $\begin{array}{l}2 \cdot 79 \\
4 \cdot 59 \\
7 \cdot 44\end{array}$ & $\begin{array}{l}0.095 \\
0.032 \\
0.006\end{array}$ \\
\hline $\begin{array}{l}\text { Siblings only: } \\
\text { Jewish probands } \\
\text { Non-Jewish probands } \\
\text { All probands }\end{array}$ & $\begin{array}{l}(8 \cdot 0) v \\
(3 \cdot 0) v \\
(8 \cdot 0,3 .\end{array}$ & $\begin{array}{l}\cdot 4) \\
\text { 4) } \\
v(2 \cdot 4,0 \cdot 4)\end{array}$ & $\begin{array}{r}7 \cdot 68 \\
5 \cdot 30 \\
11 \cdot 48\end{array}$ & $\begin{array}{l}0.006 \\
0 \cdot 021 \\
0.001\end{array}$ \\
\hline
\end{tabular}

$\mathrm{CD}=$ Crohn's disease $\mathrm{UC}=$ ulcerative colitis . presents the results of comparisons between Jewish and non-Jewish probands for Crohn's disease probands only, ulcerative colitis only and the combination of both. Table VI (C) shows the results of comparisons between probands with Crohn's disease and those with ulcerative colitis for Jewish and non-Jewish probands, and the combination of both. The crude empirical risks were higher among Jews than non-Jews. This was consistent for probands with Crohn's disease $(p=0.086)$ and for those with ulcerative colitis $(p=0.045)$. To evaluate the overall difference between the Jewish and non-Jewish families, we calculated the Mantel-Haenszel statistics by considering ulcerative colitis and Crohn's disease as two strata and obtained a very significant difference $(p=0.009)$. In addition, the prevalence of inflammatory bowel disease was higher in first degree relatives of Crohn's disease probands than in those of patients with ulcerative colitis, and this was true for both Jews and non-Jews $(4.5 \% v 2.6 \%$ in Jews, $\mathrm{p}=0.095 ; 2.7 \% v 0.9 \%$ in non-Jews, $p=0.032$; and overall $p=0.006$ ). To test further the validity of these conclusions, all comparisons were also repeated by restricting the analysis to siblings of the probands only, since this is the group which has both the most accurate information and has also lived through an extended period of risk. The results from the analyses restricted to siblings only showed the same basic outcomes, and yielded even greater statistical significance values than the results derived from all the first degree relatives combined (the lower portions of Tables VI (B) and (C) respectively).

The age adjusted risk estimates for inflammatory bowel disease for siblings, parents, children, and for all first degree relatives combined as calculated by the Strömgren method are given in Table VII (A). The results of comparisons between Jewish and non-Jewish probands, and between Crohn's disease and ulcerative colitis probands, are given in Table VII (B) and $(C)$ respectively. It should be noted that the calculated number of individuals at risk after adjustment for age decreased dramatically, especially in children, as a result of the large proportion of younger individuals in this latter group. As described in the methods section, the denominator was adjusted based on the proportional risk by age in the general population that is, a younger person contributed less weight than an older person (see Table I) to the 'lifetime.' In general, as for the crude empirical risk estimations, the relatives of Jewish probands have an increased age adjusted risk compared with the relatives of non-Jewish probands (for Crohn's: disease $7 \cdot 8 \%$ v $5 \cdot 2 \%$, for ulcerative colitis: $4.5 \% \quad v 1.6 \%$, overall comparison $\mathrm{p}=0.028)$. This is especially so for the siblings (for Crohn's disease: $16 \cdot 8 \% v 7 \cdot 0 \%$, for ulcerative colitis: $4.6 \% v 0.9 \%$, overall $\mathrm{p}=0.01$ ). The relatives of Crohn's disease probands have an increased risk compared with those of ulcerative colitis probands ( $p=0.063$ in Jews, $p=0.028$ in non-Jews, and the overall group, $\mathrm{p}<0.005$ ). Figure 1 indicates the age adjusted risk estimates for inflammatory bowel disease for the first degree relatives, both by the form of inflammatory bowel disease in the proband (ulcerative 
TABLE VII (A) Lifetime risk among the first degree relatives of patients with inflammatory bowel disease

\begin{tabular}{|c|c|c|c|c|}
\hline & Siblings $\%(\text { no })^{\star}$ & Parents $\%(\text { no })^{\star}$ & Offspring $\%(n o)^{\star}$ & $\begin{array}{l}\text { All first degree } \\
\%(\text { no })^{\star}\end{array}$ \\
\hline $\begin{array}{l}\text { Jews: } \\
\text { CD patients } \\
\text { UC patients }\end{array}$ & $\begin{array}{c}16 \cdot 8(95) \\
4 \cdot 6(131)\end{array}$ & $\begin{array}{l}3 \cdot 8(211) \\
4 \cdot 1(247)\end{array}$ & $\begin{array}{l}7 \cdot 4(27) \\
7 \cdot 4(41)\end{array}$ & $\begin{array}{l}7 \cdot 8(333) \\
4 \cdot 5(418)\end{array}$ \\
\hline $\begin{array}{l}\text { Non-Jews: } \\
\text { CD patients } \\
\text { UC patients }\end{array}$ & $\begin{array}{l}7 \cdot 0(115) \\
0 \cdot 9(114)\end{array}$ & $\begin{array}{l}4 \cdot 8(187) \\
1 \cdot 2(168)\end{array}$ & $\begin{array}{c}0(23) \\
11 \cdot 0(18)\end{array}$ & $\begin{array}{l}5 \cdot 2(325) \\
1 \cdot 6(300)\end{array}$ \\
\hline \multicolumn{3}{|c|}{$\begin{array}{c}\text { (B) Statistical comparisons between fews and non-fews } \\
\text { Rates compared }\end{array}$} & $\chi_{M H^{2}}$ & p value \\
\hline $\begin{array}{l}\text { All first degree relatives: } \\
\text { CD probands } \\
\text { UC probands } \\
\text { All probands }\end{array}$ & \multicolumn{2}{|c|}{$\begin{array}{l}(16 \cdot 8,3 \cdot 8,7 \cdot 4) v(7 \cdot 0,4 \cdot 8,0) \\
(4 \cdot 6,4 \cdot 1,7 \cdot 4) v(0 \cdot 9,1 \cdot 2,11 \cdot 0) \\
(7 \cdot 8,4 \cdot 5) v(5 \cdot 2,1 \cdot 6)\end{array}$} & $\begin{array}{l}2 \cdot 10 \\
3 \cdot 12 \\
4 \cdot 83\end{array}$ & $\begin{array}{l}0 \cdot 147 \\
0 \cdot 078 \\
0 \cdot 028\end{array}$ \\
\hline $\begin{array}{l}\text { Siblings only: } \\
\text { CD probands } \\
\text { UC probands } \\
\text { All probands } \\
\end{array}$ & \multicolumn{2}{|c|}{$\begin{array}{l}(16 \cdot 8) v(7 \cdot 0) \\
(4 \cdot 6) v(0 \cdot 9) \\
(16 \cdot 8,4 \cdot 6) v(7 \cdot 0,0 \cdot 9)\end{array}$} & $\begin{array}{l}5 \cdot 02 \\
3 \cdot 01 \\
6 \cdot 68\end{array}$ & $\begin{array}{l}0.025 \\
0 \cdot 083 \\
0.010\end{array}$ \\
\hline \multicolumn{3}{|c|}{$\begin{array}{r}\text { (C) Statistical comparisons between } C D \text { and UC } \\
\text { Rates compared }\end{array}$} & $\chi_{M H^{2}}$ & p value \\
\hline $\begin{array}{l}\text { All first degree relatives: } \\
\text { Jewish probands } \\
\text { Non-Jewish probands } \\
\text { All probands }\end{array}$ & $\begin{array}{l}(16 \cdot 8,3 \cdot \\
(7 \cdot 0,4 \cdot 8 \\
(7 \cdot 8,5 \cdot 2\end{array}$ & $\begin{array}{l}3 \cdot 7 \cdot 4) v(4 \cdot 6,4 \cdot 1,7 \cdot 4) \\
0) v(0 \cdot 9,1 \cdot 2,11 \cdot 0) \\
v(4 \cdot 5,1 \cdot 6)\end{array}$ & $\begin{array}{l}3 \cdot 47 \\
4 \cdot 82 \\
7 \cdot 83\end{array}$ & $\begin{array}{l}0.063 \\
0.028 \\
0.005\end{array}$ \\
\hline $\begin{array}{l}\text { Siblings only: } \\
\text { Jewish probands } \\
\text { Non-Jewish probands } \\
\text { All probands }\end{array}$ & $\begin{array}{l}(16 \cdot 8) v \\
(7 \cdot 0) v( \\
(16 \cdot 8,7\end{array}$ & $\begin{array}{l}4 \cdot 6) \\
\cdot 9) \\
v(4 \cdot 6,0 \cdot 9)\end{array}$ & $\begin{array}{r}9 \cdot 42 \\
5 \cdot 60 \\
13 \cdot 47\end{array}$ & $\begin{array}{l}0.002 \\
0.018 \\
0.000\end{array}$ \\
\hline
\end{tabular}

^Age adjusted number of relatives.

$\mathrm{CD}=$ Crohn's disease; $\mathrm{UC}=$ ulcerative colitis

colitis $v$ Crohn's disease) and the ethnicity of the probands (Jews $v$ non-Jews).

Table VII (A) also indicates that the parents have a lower age adjusted risk than the siblings and children of the probands, especially in Jews. Some possible explanations for the lower risk in parents of probands will be discussed below. The estimates of empirical risks for children should also be considered cautiously because of the moderate number in the denominator. The assessments of age adjusted empirical risk for inflammatory bowel disease in the siblings of probands, therefore, are likely to be the most

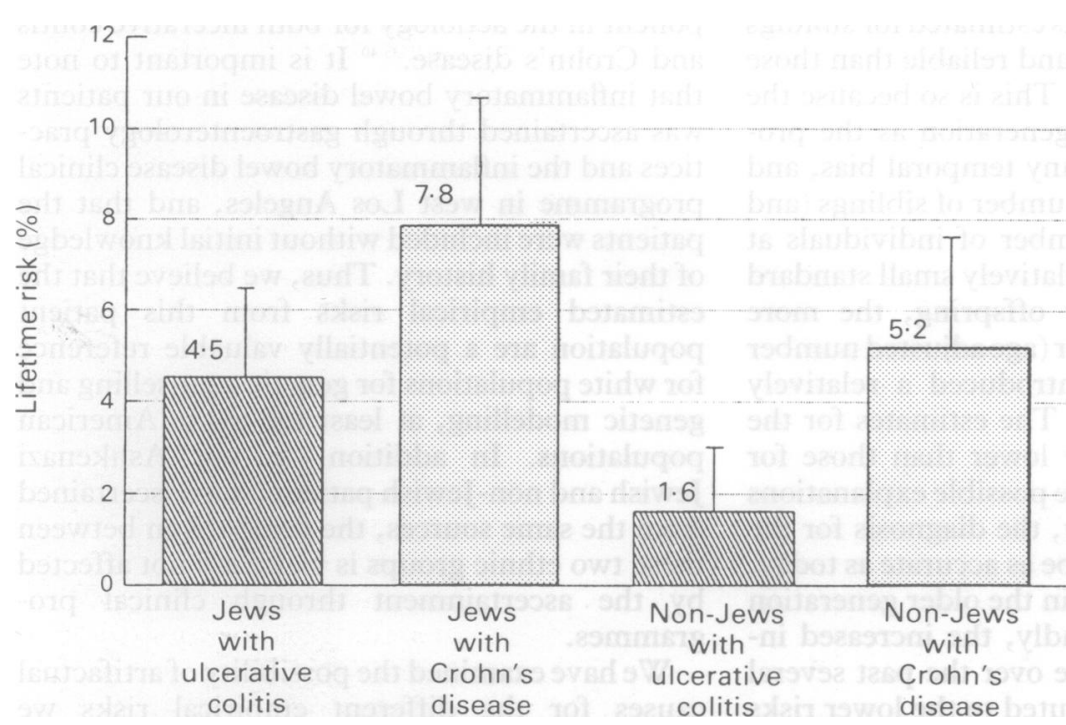

Estimates of lifetime risks for inflammatory bowel disease in the first degree relatives of ulcerative colitis and of Crohn's disease probands and their $95 \%$ confidence intervals, for $\mathcal{F}$ ews and non-Fews, respectively. Relatives of Crohn's disease probands had an increased risk compared with those of ulcerative colitis probands $(p=0.005)$. Relatives of Fewish patients had a greater risk than relatives of non-fewish patients $(p=0.028)$. useful and reliable estimates for genetic counselling and genetic modelling. Thus, comparisons have been made using all first degree relatives (Tables VI (B) and VII (B)) and again restricting the comparisons to siblings only (Tables VI (C) and VII (C)). This latter comparison regarding siblings is likely to be particularly accurate since there are a large number of siblings and they are in the same generation as the probands, which would reduce any bias introduced by temporal changes.

\section{Discussion}

Age adjusted empirical risks of inflammatory bowel disease for relatives of non-Jewish white patients with ulcerative colitis or Crohn's disease are reported here for the first time. We were also able to increase our series of American Ashkenazi Jewish patients for these empirical risk estimations. This allowed a critical comparison of the familial risks for the two ethnic groups in the same geographical area. We found that the estimates of age adjusted empirical risks for inflammatory bowel disease in the relatives of the white non-Jewish patients were significantly lower than those for relatives of Jewish patients. Because the pattern of inheritance in inflammatory bowel disease is not generally considered to be consistent with any simple Mendelian model and there are, as yet, no accepted genetic markers available for risk assessment, accurate empirical risk estimates are needed for genetic counselling. The data presented herein indicate that there are significantly different familial empirical risks in the Jewish and non-Jewish inflammatory bowel disease populations. Thus, it is likely that individualised risk estimates for each major ethnic group are needed to provide optimal genetic counselling, as well as for formal mathematical modelling and genetic analysis.

Given the data regarding twins, spouses, and distant family members, it seems that the principal contribution to familial aggregation is genetic susceptibility. An examination of the differences in familial empirical risks between Jews and non-Jews also contributes therefore to the understanding of the genetic aetiologies of inflammatory bowel disease. There are currently several models of the genetic susceptibility: the simple Mendelian models, the polygenic/multifactorial model, the multilocus/oligogenic model, and the genetic heterogeneity model. ${ }^{3}$ Using a formal genetic analytical technique called complex segregation analysis on amnestic family data, a recessive gene with incomplete penetrance was recently suggested for Crohn's disease, ${ }^{2+}$ while an additive major gene was similarly proposed for ulcerative colitis. ${ }^{25}$ If a single Mendelian gene is responsible for the susceptibility of either ulcerative colitis or Crohn's disease (or both), we would expect to observe the same empirical risks in the first degree relatives of probands in Jews and non-Jews even if there is a different population incidence in these two populations. That is because, for a simple Mendelian disease, the risks for the relatives of an affected proband depend on the mode of inheritance, while the different incidences in the population are the result of different gene fre- 
quencies. For example, Ashkenazi Jews have an increased incidence of Tay-Sachs disease compared with non-Jews, ${ }^{26}$ yet the siblings of a proband with Tay-Sachs disease have the same risk of developing the disease $(25 \%)$ whether they are Jews or non-Jews. Therefore, the difference in the population incidence rates ${ }^{27-30}$ and in the familial empirical risks between Jews and non-Jews who are from the same geographical areas allow the formal rejection of the single Mendelian models (even with reduced penetrance) for inflammatory bowel disease or its clinical subtypes of ulcerative colitis and Crohn's disease. Such results could be the result of a different mode of inheritance in the two populations - for example Jews having one mode and non-Jews a different mode of inheritance for inflammatory bowel disease and/or because of the existence of the mixture of several modes of inheritance in each population with each population consisting of different proportions of each type of inheritance. These latter speculations are consistent with the genetic heterogeneity model supported by emerging genetic marker and subclinical marker data. ${ }^{31-34}$ The observation in these data that there was a difference in the proportion of families with both forms of inflammatory bowel disease - that is ulcerative colitis and Crohn's disease simultaneously - between Jewish and non-Jewish families are also consistent with the heterogeneity model. However, the current empirical risk data do not by themselves allow us to distinguish between these remaining different models - that is the multifactorial, multilocus, and genetic heterogeneity models. In addition, these empirical risks in relatives may be modified by other factors which were not measured here, such as smoking. The interactions between genetic and potential environmental factors will need to be evaluated to identify fully the appropriate aetiological models for ulcerative colitis and Crohn's disease. To do this adequately, however, may require the ability to identify which of the relatives are at risk, by identifying the actual genetic susceptibilities. ${ }^{31-34}$

For genetic counselling purposes, we would consider the empirical risks estimated for siblings of probands more robust and reliable than those for parents and offspring. This is so because the siblings are in the same generation as the probands, which minimises any temporal bias, and because there are a large number of siblings (and thus a large adjusted number of individuals at risk), which results in a relatively small standard error of estimation. For offspring, the more modest size of denominator (age adjusted number of individuals at risk) introduced a relatively large confidence interval. The estimates for the parents were consistently lower than those for siblings and offspring. The possible explanations may be as follows. Firstly, the diagnosis for the older generation may not be as accurate as today, so that a number of cases in the older generation went undiagnosed. Secondly, the increased incidence of Crohn's disease over the past several decades may have contributed to the lower risks for parents compared with siblings and offspring, though most data supporting these trends have been reported from the United Kingdom and Scandinavia. ${ }^{35}$
These age adjusted risks are the lifetime risks for inflammatory bowel disease based on the assumption that all individuals will live to 70 years and experience the same distribution of proportional risk as the Baltimore population studied by Calkins et al. ${ }^{21}$ Even if the latter is not the case, the comparisons between different groups are valid as long as the same standard distribution of proportional risk is used for all groups. However, the usefulness of empirical risk estimates for genetic counselling and modelling would depend on the accuracy of the assumption that all individuals will experience the same distribution of proportional risks as the one reported by Calkins et al ${ }^{21}$ Since there was no data available from Los Angeles for us to evaluate this assumption directly, we compared the data of Calkins et al with two other US population based data sets: (1) the incidence data of Crohn's disease among residents of Olmsted County, Minnesota, 1943-1982 ${ }^{36}$; and (2) the incidence data of ulcerative colitis among residents of Rochester, Minnesota, 1960-1979. ${ }^{37}$ The results were virtually identical. These comparisons suggested that there was a similar distribution of proportional risks among all three US populations, even if the incidence might differ. This additional information provides some assurance in the more general use of the empirical risk estimates reported herein for American inflammatory bowel disease patients.

The sample of inflammatory bowel disease patients used to estimate familial empirical risks in the current study is not a population based sample, and is thus similar to most other reported empirical risk data for inflammatory bowel disease as well as other diseases. ${ }^{38}{ }^{39}$ The studied patient population is white (Ashkenazi Jews and non-Jews) and of middle or upper socioeconomic status. The extensive reviews of risk factors for inflammatory bowel disease by numerous authors have failed to identify any confirmed environmental factors associated with its development, including socioeconomic status, diet, bacterial and viral infection, and drugs, but all have indicated that there is a genetic component in the aetiology for both ulcerative colitis and Crohn's disease. ${ }^{35}{ }^{40}$ It is important to note that inflammatory bowel disease in our patients was ascertained through gastroenterology practices and the inflammatory bowel disease clinical programme in west Los Angeles, and that the patients were included without initial knowledge of their family history. Thus, we believe that the estimated empirical risks from this patient population are a potentially valuable reference for white populations for genetic counselling and genetic modelling, at least for white American populations. In addition, as our Ashkenazi Jewish and non-Jewish patients were ascertained from the same sources, the comparison between these two ethnic groups is valid and not affected by the ascertainment through clinical programmes.

We have examined the possibility of artifactual causes for the different empirical risks we observed between Jews and non-Jews. As regards empirical risk estimation, a longer duration of disease may result in an individual being more aware of the disease and more likely to 
know more about his or her relatives' medical problems, especially those affected by the same disease - that is inflammatory bowel disease. Thus, we have also examined the relation between the duration of the disease with the frequency of a positive family history of inflammatory bowel disease. There is no association between these two variables in our data, and this is true both for the Jews and non-Jews. Therefore, disease duration was not an explanation for the difference in empirical risks between Jews and non-Jews. In addition, family size and age distributions of relatives did not account for these differences. Since the total number of affected first degree relatives was 45 in Jews and 22 in non-Jews, it is possible that a few unusual families could bias the representativeness of the whole sample. In other words, if, for example, some families had clearly dominant inheritance with $50 \%$ of first degree relatives affected, the inclusion of these families with different frequencies in Jews and non-Jews would make a large difference in the risk estimation for the whole sample. Therefore, we have also examined the distribution of affected individuals in the families (Table III). It did not show any particular large cluster in the Jewish group.

It has previously been reported that familial cases tend to have a younger age of onset. ${ }^{+1}$ It seems that this finding is principally in ulcerative colitis patients. We observed that there was a significant difference in age at onset between ulcerative colitis and Crohn's disease, and that this difference was dependent on those with a positive family history of inflammatory bowel disease. Our patients with Crohn's disease had an earlier age of onset than those with ulcerative colitis, and our ulcerative colitis patients with positive family history of inflammatory bowel disease had an earlier onset than those without a family history of inflammatory bowel disease. These data indicate that, at least in ulcerative colitis, familial cases tended to have an earlier age of onset than non-familial cases. A similar finding has been reported in other studies. ${ }^{42}$ If this also applies to Crohn's disease, it may be that most cases of Crohn's disease were genetically determined, leading to their average younger age of onset than that of the ulcerative colitis patients, even if the individual Crohn's disease patient does not have a positive family history. These data and this suggestion are consistent with the data from twin and family studies which show that Crohn's disease co-twins have a greater concordance rates than ulcerative colitis cotwins, and that relatives of Crohn's disease patients have a higher risk for inflammatory bowel disease than those of ulcerative colitis patients. ${ }^{1617+1+34}$ In this study, we have also shown that relatives of Crohn's disease probands have a significantly increased life time risk compared with relatives of ulcerative colitis probands, and this was true in both Jews and non-Jews.

It has also been observed by others that ulcerative colitis and Crohn's disease occur with higher than expected frequency in the same family, and that Crohn's disease probands tended to have a higher frequency of relatives affected with ulcerative colitis than ulcerative colitis probands have relatives affected with Crohn's disease. ${ }^{151718+3+4}$ Both our Jewish and nonJewish data are consistent with these previous observations. All these observations are compatible with the suggestion that ulcerative colitis and Crohn's disease (or a subgroup) share a genetic background and that the genetic component plays a more important or more determinative role in Crohn's disease than in ulcerative colitis.

In summary, we have estimated the familial empirical risks for inflammatory bowel disease in the first degree relatives of Jewish and nonJewish probands with ulcerative colitis or Crohn's disease ascertained from the same geographic area, taking into account the age distribution in relatives. These estimates are important for genetic counselling and genetic modelling. The degree of familiality indicated by the age adjusted empirical risks for inflammatory bowel disease in the first degree relatives is greater in Jews than that in non-Jews. An increased incidence rate of inflammatory bowel disease in the Jewish population and an increased risk for inflammatory bowel disease in the relatives of Jewish probands indicate formally that a single Mendelian gene model for the susceptibility to ulcerative colitis or Crohn's disease is unlikely. Although the genetic heterogeneity model seems most likely given the data from genetic marker and subclinical marker studies, the multifactorial model and the multilocus models cannot be excluded with these empirical risk data alone. These results indicate the importance of carefully defining the familial empirical risks in a variety of populations and ethnic groups.

This work has been supported by NIH grant DK36200, and grants from the Crohn's and Colitis Foundation of America, the grants from the Crohn's and Colitis Foundation of America, the in Medical Genetics (JIR).

1 Gilat T, Grossman A, Fireman Z, Rozen P. Inflammatory bowel disease in Jews. In: McConnell R, Rozen P, Langma $\mathrm{M}$, Gilat T, eds. The genetics and epidemiology of inflammatory bowel disease. New York: Karger, 1986: 135-40.

2 Rotter JI, Yang H, Shohat T. Genetic complexities of inflammatory bowel disease and its distribution among the Jewis people. In: B Bonne-Tamir, A Adam, eds Genetic diversity among fews: disease and markers at the DNA level. Oxford: Oxford University Press, 1992: 395-411.

3 Yang H, Shohat T, Rotter JI. The genetics of inflammatory bowel disease. In: R MacDermott, W Stenson, eds. Inflambowel disease. In: R MacDermott, W Stenson, eds. In

4 Gilat T, Ribak J, Benaroya Y, Zemishlany Z, Weissman I. Ulcerative colitis in the Jewish population of Tel-Aviv-Jafo. Ulcerative colitis in the Jewish population of Tel-Aviv-

I. Epidemiology. Gastroenterology 1974; 66: 335-42.
Rozen P, Zonis J, Yekutiel P, Gilat T. Crohn's disease in the Jewish population of Tel-Aviv-Jafo. Epidemiologic and clinical aspects. Gastroenterology 1979; 76: 25-30.

6 Krawiec J, Odes HS, Lasry Y, Krugliak P, Weitzman S. Aspects of the epidemiology of Crohn's disease in the Jewish population in Beer Sheva, Israel. Isr f Med Sci 1984; 20 : 16-21.

7 Odes HS, Fraser D, Krawiec J. Incidence of idiopathic ulcerative colitis in Jewish population subgroups in the Beer Sheva region of Israel. Am $\mathcal{F}$ Gastroenterol 1987; 82. $854-8$.

8 Odes HS, Fraser D, Krawiec J. Ulcerative colitis in the Jewish population of southern Israel 1961-1985: epidemiological population of southern 1srael 1961-1985:

9 Roth M-P, Petersen GM, McElree C, Feldman E, Rotter JI Geographic origins of Jewish patients with inflammatory Geographic origins of Jewish patients with in
bowel disease. Gastroenterology 1989; $97: 900-4$.

10 Zlotogora J, Zimmerman J, Rachmilewitz D. Crohn's disease in Ashkenazi Jews. Gastroenterology 1990; 99: 286-7.

11 Odes HA, Fraser D, Krawiec J. Inflammatory bowel disease in migrant and native Jewish populations of southern Israel. Scand F Gastroenterol 1989; 24 (suppl 170): 36-8.

12 Odes HA, Fraser D, Krugliak P, Fenyves D, Fraser GM Sperber AD. Inflammatory bowel disease in the Bedouin Arabs of southern Israel: rarity of diagnosis and clinical features. Gut 1991; 32: 1024-6. 
13 Orholm M, Munkholm P, Langholz E, Nielsen OH, Srensen IA, Binder V. Familial occurrence of inflammatory bowe disease. N Engl f Med 1991; 324: 84-8.

14 Weterman IT, Pena AS. Familial incidence of Crohn's disease in the Netherlands and a review of the literature Gastroenterology 1984; 86: 449-52.

15 McConnell RB. Genetics of inflammatory bowel disease. In Allan RN, Keighley MRB, Alexander-Williams J, Hawkin $\mathrm{CF}$, eds. Inflammatory bowel disease. New York: Churchill CF, eds. Inflammatory bowel

16 Tysk C, Lindberg E, Jarnerot G, Floderus-Myrhed B. Ulcerative colitis and Crohn's disease in an unselected population of monozygotic and dizygotic twins. A study of heritability and the influence of smoking. Gut 1988; 29: 990-6.

17 Kirsner JB. Genetic aspects of inflammatory bowel disease. Clin Gastroenterol 1973; 2: 557-76.

18 Roth M-P, Petersen GM, McElree C, Vadheim CM, Panish JF, Rotter JI. Familial recurrence risk estimates of inflammatory bowel disease in Ashkenazi Jews. Gastroenterology 1989; 96: 1016-20.

19 Köbberling J, Untersuchungen zur Genetik des Diabetes mellitus. Eine geeignete Methode zur Durchführung von Alterskorrekturen. Diabetologia 1969; 5: 392-6.

20 Tillil H, Köbberling J. Age-corrected empirical genetic risk estimates for first-degree relatives of IDDM patients. estimates for first-degr

21 Calkins BM, Lilienfeld AM, Garland CF, Mendeloff AI. Trends in incidence rates of ulcerative colitis and Crohn' disease. Dig Dis Sci 1984; 29: 913-20.

22 Snedecor GW, Cochran WG. Statistical methods. Iowa: The Iowa State University Press, 1980

23 Rothman KJ. Modern epidemiology. Boston: Little, Brown an Company, 1986: 177-236.

24 Kuster W, Pascoe L, Purrmann J, Funk S, Majewski F. The genetics of Crohn disease: complex segregation analysis of a family study with 265 patients with Crohn disease and 5387 relatives. Am F Med Genet 1989; 32: 105-8.

25 Monsén U, Iselius L, Johansson C, Hellers G. Evidence for a major additive gene in ulcerative colitis. Clin Genet 1989; $36:$ major 4 .

26 Kolodny EH. Tay-Sachs disease. In: Goodman RM, Motulsky AG, eds. Genetic disease among Ashkenazi fews. New York: Raven Press, 1979: 217-29.

27 Monk M, Mendeloff AI, Siegel CI, Lilienfeld A. An epidemiological study of ulcerative colitis and regional enteritis among adults in Baltimore. I. Hospital incidence an prevalence, 1960-1963. Gastroenterology 1967; 53: 198-210.

28 Brahme F, Lindstrom C, Wenckert A. Crohn's disease in defined population. An epidemiological study of incidence, prevalence, mortality and secular trends in the city of Malmo, Sweden. Gastroenterology 1975; 69: 342-51.

29 Hellers G. Crohn's disease in Stockholm county, 1955-1974: study of epidemiology, results of surgical treatment and long term prognosis. Acta Chir Scand 1979; 490 (Suppl): 1-84.

30 Novis BH, Marks IN, Bank S, Louw JH. Incidence of Crohn's disease at Groote Schuur Hospital during 1970-1974. $S$ Afr Med F 1975; 49: 693-7.

31 Rotter JI, Wang S-J, Yang H, McElree CK, Pressman S, et al. Genetic heterogeneity between ulcerative colitis (UC) and Crohn's disease (CD) identified by molecular HLA class II association. Gastroentrology 1992; 102: A688.

32 Shanahan F, Duerr R, Rotter JI, Yang H, Sutherland L, et al. Neutrophil autoantibodies in ulcerative colitis: familial Neutrophil autoantibodies in ulcerative colitis: familial aggregation and

33 Rotter JI, Shohat T, Vadheim CM. Is IBD a genetic disease? In: D Rachmilewitz and J Zimmerman, eds. Inflammatory bowel diseases 1990. Dordrecht, The Netherlands: Kluwe Academic Publishers, 1990: 5-18.

34 Rotter JI. Immunogenetic susceptibilities in IBD. Canad f Gastroenterol 1990; 4: 261-6.

35 Langman MJS. Epidemiology of inflammatory bowel disease. In. Allan RN, Keighley MRB, Alexander-Williams J, Hawkins CF, eds. Inflammatory bowel disease New York: Churchill Livingstone, 1990: 24-33.

36 Gollop JH, Philips SF, Melton LJ, Zinsmeister AR Epidemiologic aspects of Crohn's disease: a population based demiologic aspects of Crohn's disease: a population based 29: 49-56.

37 Stonnington CM, Philips SF, Melton LJ, Zinsmeister AR. Chronic ulcerative colitis: incidence and prevalence in a community. Gut 1987; 28: 402-9.

38 Sadovnick AD, Irwin ME, Baird PA, Beattie BL. Genetic studies on an Alzheimer clinic population. Genetic Epidemiology 1989; 6: 633-43

39 Sadovnick AD, Baird PA. The familial nature of multiple sclerosis: age-corrected empiric recurrence risks for children and siblings of patients. Neurology 1988; 38: 990-1.

40 Ekbom A, Adami H-O. The epidemiology of inflammatory bowel disease. In MacDermott R, Stenson WF, eds. Inflammatory bowel disease. New York: Elsevier, 1992: 1-15.

41 Farmer RG, Michener WM, Mortimer EA. Studies of family history among patients with inflammatory bowel disease. history among patients with inflan
Clin Gastroenterol 1980; $9: 271-7$.

42 Monsén U, Broström O, Nordenvall B, Sörstad J, Hellers G. Prevalence of inflammatory bowel disease among relatives of patients with ulcerative colitis. Scand $\mathcal{F}$ Gastroenterol 1987 22: $214-8$

43 Kirsner JB, Spencer JA: Family occurrences of ulcerative colitis, regional enteritis and ileocolitis. Ann Int Med 1963; 59: $133-44$.

44 Lashner BA, Evans AA, Kirsner JB, Hanauer SB. Prevalence and incidence of inflammatory bowel disease in family members. Gastroenterologv 1986; 91 : 1396-400. 